\title{
A PÉNZMOSÁS ÉS TERRORIZMUSFINANSZÍROZÁS ELLENI KÜZDELEM AZ ÉSZAK-AFRIKAI ÉS KÖZEL- KELETI RÉGIÓBAN
}

\author{
The Fight Against Money Laundering and Terrorist Financing in \\ North Africa and Middle East
}

\section{Tóth Zoltán Balázs ${ }^{12}$}

\begin{abstract}
Absztrakt: Az észak-afrikai és közel-keleti régióban komoly kihívást jelent a pénzmosással és terrorizmusfinanszírozással felmerülő kockázatok kezelése. A Pénzügyi Akciócsoport (angol elnevezés: Financial Action Task Force) ajánlásainak átültetése több országban hosszú éveken át elnyúló folyamat, míg az úgynevezett törékeny államok esetében a szabályozási környezet átalakítása és a gyakorlatban történő alkalmazása nehezen kivitelezhető feladat. A több országban is tapasztalható polgárháborús állapotok - lásd Jemen, Líbia, Szíria, - megnehezítik a gazdasági bűncselekmények és a terrorizmussal szembeni hatékony fellépést - a kettô néha összemosódik -, amely értelemszerűen kihatással van azon országokra is, ahol érdemben foglalkoznak a témával.
\end{abstract}

Kulcsszavak: Észak-Afrika, Közel-Kelet, Pénzügyi Akciócsoport, pénzmosás, terrorizmusfinanszírozás, nemzetközi együttmúködés

Abstract: Managing the risks posed by money laundering and terrorist financing is a serious challenge in the North African and Middle Eastern

1 A Külügyi Mưhely c. online tudományos folyóirat fôszerkesztője, valamint a Nemzeti Közszolgálati Egyetem, Közigazgatás-tudományi Doktori Iskola, doktoranduszhallgató. Email címe: toth.zoltanbalazs@gmail.com

ORCID: https://orcid.org/0000-0002-9999-2841

A szerzô további munkásságát lásd a Magyar Tudományos Művek Tára oldalán: https: $/ / \mathrm{m} 2 . \mathrm{mtmt}$. hu/gui2 $/$ ?type $=$ authors\&mode=browse\&sel $=10061240$

${ }^{2}$ A tanulmány a Young Leaders Fellowship Fund - Fiatal Vezetők Ösztöndíja Alapítvány által támogatott, Az észak-afrikai országok bilaterális gazdasági kapcsolatainak alakulása az Európai Unióval és nemzetközi szervezetekkel 2011. után c. kutatásnak köszönhetően jelenhetett meg. 
regions. The implementation of the Financial Action Task Force's recommendations is a long-term process in many countries, not to mention that in fragile states the development and implementation of the regulatory environment is a difficult task. In the countries affected by civil wars Libya, Syria, Yemen - makes the fight against economic crime and terrorism harder - sometimes have a strong connection between them - which obviously have an impact on the other countries as well.

Keywords: North Africa, Middle East, Financial Action Task Force, money laundering, terrorist financing, international cooperation

\section{BEVEZETÉS}

A Pénzügyi Akciócsoport (angol elnevezés: Financial Action Task Force, a továbbiakban rövidítve: FATF) egy adott szakpolitika mentén - jelen esetben a pénzmosás és terrorizmusfinanszírozás visszaszorítása - hozott létre olyan nemzetközi rezsimet, amellyel a globális kormányzás prototípusává vált. ${ }^{3} \mathrm{~A} z$ FATF tevékenysége mértékadóvá vált az országok és nemzetközi szervezetek számára egyaránt, továbbá módszertana és ajánlásai aktívan alakítják az egyes országok szabályozási környezetét.

Az FATF jelenleg 39 taggal rendelkezik, amely 37 országból, az Európai Bizottságból, valamint az Öböl Menti Együttmúködési Tanácsból tevődik össze. Társult tagként múködnek az úgynevezett FATF-szerú Regionális Testületek (angol elnevezés: FATF-Style Regional Bodies), amelyek a helyi sajátosságokhoz jobban igazodva igyekeznek átültetni az FATF ajánlásait a gyakorlatba. Az észak-afrikai és közel-keleti régió vonatkozásában az úgynevezett MENAFATF (angol elnevezés: Middle East and North Africa Financial Action Task Force) elnevezésű szervezet felel az FATF ajánlásainak minél hatékonyabb átemeléséért, valamint a nemzetközi együttmúködés előmozdításáért.

3 Az FATF részletes bemutatásáért, valamint az egyéb nemzetközi szervezetekkel kapcsolatos viszonyrendszerének áttekintéséért lásd TóTH, 2019a

4 A pénzmosás és terrorizmusfinanszírozás fogalmi hátterének áttekintésért lásd TÓTH, 2019b és TÓTH, 2019c 


\begin{tabular}{|c|c|c|}
\hline $\begin{array}{l}\text { Észak-afrikai } \\
\text { országok }^{5}\end{array}$ & FATF tagság & $\begin{array}{l}\text { MENAFATF } \\
\text { tagság }\end{array}$ \\
\hline Algéria & Nem & Igen \\
\hline Egyiptom & $\mathrm{Nem}$ & Igen \\
\hline Líbia & Nem & Igen \\
\hline Marokkó & $\mathrm{Nem}$ & Igen \\
\hline Tunézia & $\mathrm{Nem}$ & Igen \\
\hline
\end{tabular}

1. sz. táblázat. Az észak-afrikai országok FATF és MENAFATF tagságának összegzése. Forrás: https://www.fatf-gafi.org/pages/menafatf.html

\begin{tabular}{|l|l|l|}
\hline $\begin{array}{l}\text { Közel-keleti } \\
\text { országok }\end{array}$ & FATF tagság & $\begin{array}{l}\text { MENAFATF } \\
\text { tagság }\end{array}$ \\
\hline Bahrein & Igen* & Igen \\
\hline $\begin{array}{l}\text { Egyesült } \\
\text { Emírségek }\end{array}$ & Agen * & Igen \\
\hline Irak & Nem & Igen \\
\hline Irán & Nem & Nem \\
\hline Izrael & Igen & Nem \\
\hline Jemen & Nem & Igen \\
\hline Jordánia & Nem & Igen \\
\hline Katar & Igen $*$ & Igen \\
\hline Kuvait & Igen $*$ & Igen \\
\hline Libanon & Nem & Igen \\
\hline Omán & Igen $*$ & Igen \\
\hline Szaúd-Arábia & Igen & Igen \\
\hline Szíria & Nem & Igen \\
\hline
\end{tabular}

2. sz. táblázat. A közel-keleti országok FATF és MENAFATF tagságának összegzése. A csillaggal jelölt országok az Öböl Menti Együttműködési

5 Az ENSZ statisztikai besorolása még Nyugat-Szaharát és Szudánt is az észak-afrikai régióhoz sorolja, de saját megfontolásból ezen két államot nem vontam be a vizsgálat fókuszába. Forrás: METHODOLOGY - STANDARD COUNTRY OR AREA CODES FOR STATISTICAL USE (M49)

6 Az ENSZ statisztikai besorolása még Azerbajdzsánt, Ciprust, Örményországot, és Törökországot is a közel-keleti régióhoz sorolja, de saját megfontolásból ezen két államot nem vontam be a vizsgálat fókuszába. Továbbá fontosnak tartottam Iránt is beemelni a kutatásba, mivel a közel-keleti események aktív alakítója. Forrás: METHODOLOGY STANDARD COUNTRY OR AREA CODES FOR STATISTICAL USE (M49) 
A pénzmosás és terrorizmusfinanszírozás elleni küzdelem az észak-afrikai és közel-keleti régióban

Tanács képviseletében csatornázhatják be érdekeiket az FATF-ben. Forrás: https://www.fatf-gafi.org/pages/menafatf.html

Az FATF módszertana az elmúlt évtizedekben folyamatosan fejlődött annak érdekében, hogy minél hatékonyabban tudjon reagálni kihívásokra, kockázatokra. Az egyes országoknak ennek megfelelôen szükséges lekövetni ezen változásokat, amelyekről az FATF szakértôi helyszíni szemlékkel (angol elnevezés: on-site visit) győződnek meg. A helyszíni szemléket úgynevezett országjelentések (angol elnevezés: Mutual Evaluation Report) publikálása követi, amelynek két kimenetele lehet: 1, az adott ország nyomon követési eljárás alá kerül (angol elnevezés: Follow-up Process) ${ }^{7}$; 2 , az adott ország szabályozási környezetében súlyos hiányosságokat állapítanak (az angol elnevezésú, Improving Global AML/CFT Compliance: On-going Process - úgynevezett szürke lista alá kerülnek). ${ }^{8}$ Léteznek olyan országok, amelyek nem hajlandók érdemben együttmúködni az FATF-el, huzamosabb ideje ide tartozik Irán és Észak-Korea (az angol elnevezésű, Public Statement úgynevezett feketelista alá tartoznak). ${ }^{9}$

Az FATF módszertana az úgynevezett kockázatalapú megközelítésre épül (angol elnevezés: risk-based approach), azaz kockázat-centrikusan térképezi fel az egyes szakterületeket (például bankrendszer működése, ügyvédek, pénzváltók, adószakértôk tevékenységei, stb).

A pénzmosás és terrorizmusfinanszírozás elleni küzdelem nincsen könnyű helyzetben a régióban, köszönhetően a több országban is tapasztalható kaotikus viszonyoknak - Líbiát, Szíriát és Jement polgárháború sújtja, Irakban állandósult a belpolitikai bizonytalanság, Libanon a politikai és gazdasági összeomlás szélén táncol, míg Irán 2016-2017. óta mind kevésbé együttműködő szereplő (ráadásul miután 2018-ban az Egyesült Államok felmondta az atomalkut, egyre jobban mérgesedik el a viszony több nemzetközi szervezettel is).

7 A nyomon követési eljárás kétféle lehet attól függően, milyen mértékű hiányosságokat tárnak fel az FATF szakértői az adott ország esetében: 1, normál nyomon követési eljárás (angol elnevezés: Regular Follow-Up Process), 2, megerősített nyomon követési eljárás (angol elnevezés: Enhanced Follow-Up Process). Forrás: CONSOLIDATED PROCESSES AND Procedures For Mutual EVALUATIONS AND FOLLOW-UP, 2019. 13.o.

8 Forrás: https://www.fatf-gafi.org/fr/publications/juridictions-haut-risques-et-soussurveillance/documents/fatf-compliance-june2019.html?hf $=10 \& b=0 \& s=$ desc(fatf releasedate)

9 Forrás: https://www.fatf-gafi.org/publications/high-risk-and-other-monitoredjurisdictions/documents/public-statement-october-2019.html 
A tanulmány célja, hogy az FATF jelentésein és különböző dokumentumain keresztül bemutassa az észak-afrikai és közel-keleti országok pénzmosással és terrorizmusfinanszírozással kapcsolatos kockázatait, felhasználva természetesen további szakirodalmakat. Az országjelentésekből és egyéb dokumentumokból világosan felrajzolható az egyes országok és FATF / MENAFATF közötti viszonyrendszer, hiszen ha egy ország minél jobb értékelést ér el az FATF / MENAFATF jelentéseiben, az azt jelenti, hogy érdemben együttműködik a szervezet szakértőivel, és ennek megfelelően alakítja a politikai, gazdasági, társadalmi, stb. szereplők szabályozási környezetét. Az észak-afrikai és közel-keleti régió országai meglehetősen eltérő magatartást mutatnak a nemzetközi szervezetek vonatkozásában, így ezek megismerése hozzájárul többek között az egyes országok világgazdaságba történő integráltságuk elemzéséhez is.

A fentieknek megfelelően a tanulmány első fejezete a pénzmosás és terrorizmusfinanszírozás elméleti hátteréhez nyújt betekintést, majd az azt követő fejezet egy általános képet nyújt az észak-afrikai és közel-keleti országok kapcsán. A harmadik és negyedik fejezetten célzottan, országokra lebontva mutatja be az észak-afrikai és közel-keleti országok kockázatait az FATF dokumentumait alapul véve.

\section{A PÉNZMOSÁS ÉS TERRORIZMUSFINANSZÍROZÁS FOGALMAINAK ÁTTEKINTÉSE}

Az FATF értelmezésében a pénzmosás olyan tevékenységet jelöl, amely célja, hogy az illegális csatornákon keresztül realizált bevételeket legalizálja, ezáltal felhasználhatóvá tegye legális tranzakciókhoz. ${ }^{10}{ }^{11}$ A pénzmosás megannyi eszköz és csatorna igénybevételével megvalósulhat, és a felszámolására irányuló küzdelmet pont ez teszi nehézzé.

A terrorizmusfinanszírozás - amely a 2001. szeptember 11-i terrortámadást követően össze lett kötve a pénzmosással - nem kisebb jelentőségű kihívás, mégis, a pénzmosással kapcsolatos nemzetközi

\footnotetext{
${ }^{10}$ Korábban megjelent publikációkban számos olyan forrást dolgoztam fel, amelyek a pénzmosás elméleti megalapozását szolgálják, bővebben lásd az alábbi források irodalomjegyzékeit: TÓTH, 2019a, TÓTH, 2019b, TÓTH, 2019c

${ }^{11}$ Hasonlóan definiálja a jelenséget a pénzmosással egyik legrégebb óta foglalkozó állam, az Egyesült Államok is, alábbi hivatkozáson olvashat bővebben a módszertani megfontolásokról és az amerikai szervek témával kapcsolatos tevékenységéről: https://www.state.gov/anti-money-laundering-and-countering-the-financing-of-terrorism/
} 
összefogással összehasonlítva mintegy 10 évvel később került a fókuszba. A terrorizmusfinanszírozás elleni küzdelem a terrorizmus felszámolására irányuló nemzetközi törekvés egyik fő pillére, hiszen már a legkisebb merényleteknek is van anyagi vonzatuk - például fegyverek beszerzése, terroristák utaztatása, ellátása, stb. ${ }^{12}$

A pénzmosás és terrorizmusfinanszírozás bár jellegében különbözik egymástól, módszertani megfontolásból mégis érdemes együttkezelni. Ennek oka, hogy mindkét tevékenység a pénzügyi rendszer sérülékenységét használja ki, és hasonló csatornákon keresztül történik. Terrorista szervezetek - működésük finanszírozása érdekében - is élnek a különböző pénzmosási technikákkal, együttmúködhetnek bủnszervezetekkel, valamint maguk is működhetnek bűnszervezetként (lásd Iszlám Állam). ${ }^{13} 14$

\section{KIHÍVÁSOK AZ ÉSZAK-AFRIKAI ÉS KÖZEL-KELETI RÉGIÓBAN}

A különböző elemzőintézetek által publikált rangsorokból bárki könnyedén tájékozódhat arról, hogy az országok bizonyos szempontokból miképpen teljesítenek a többi országhoz viszonyítva. Mint az a 3. és 4. sz. táblázatokból is kitúnik, a vizsgált régió országai elég nagy szórást mutatnak.

\begin{tabular}{|l|c|c|c|}
\hline $\begin{array}{c}\text { Észak-afrikai } \\
\text { országok }\end{array}$ & $\begin{array}{c}\text { Törékeny } \\
\text { Állam Index } \\
\text { helyezés }\end{array}$ & $\begin{array}{c}\text { Globális } \\
\text { Terrorizmus } \\
\text { Index helyezés }\end{array}$ & $\begin{array}{c}\text { Korrupcióészlelési } \\
\text { Index helyezés }\end{array}$ \\
\hline Algéria & 72. & 57. & 106. \\
\hline Egyiptom & 34. & 11. & 106. \\
\hline Líbia & 28. & 12. & 168. \\
\hline Marokkó & 78. & 92. & 80. \\
\hline Tunézia & 95. & 51. & 74. \\
\hline
\end{tabular}

3. sz. táblázat. Az észak-afrikai országok globális rangsorban elfoglalt helyük a Törékeny Állam Index jelentése ${ }^{15}$, a Globális Terrorizmus Index ${ }^{16}$, valamint a Korrupcióészlelési Index ${ }^{17}$ alapján.

\footnotetext{
12 A terrorizmusfinanszírozással kapcsolatosan ajánlom Vass György PhD érdekezését.

13 HeINRICH-BÖLL-STIFTUNG - REGINE SCHÖNENBERG, 2013.

14 Lásd bővebben TóTH, 2018.

$15 \mathrm{Az}$ országok 1-178. helyezés szerint vannak besorolva, ahol az 1. helyezés a legtörékenyebb államot jelenti. Forrás: https://fragilestatesindex.org/country-data/ 16 Az országok 1-138 helyezés szerint vannak beosztva, ahol az 1. helyezés a terrorizmus kockázatainak leginkább kitett ország. Forrás: GLOBAL TERRORISM INDEX 2019, 2019.
} 


\begin{tabular}{|l|c|c|c|}
\hline \multicolumn{1}{|c|}{$\begin{array}{c}\text { Közel-keleti } \\
\text { országok }\end{array}$} & $\begin{array}{c}\text { Törékeny } \\
\text { Állam Index } \\
\text { helyezés }\end{array}$ & $\begin{array}{c}\text { Globális } \\
\text { Terrorizmus } \\
\text { Index helyezés }\end{array}$ & $\begin{array}{c}\text { Korrupcióészlelési } \\
\text { Index helyezés }\end{array}$ \\
\hline Bahrein & 113. & 61. & 77. \\
\hline $\begin{array}{l}\text { Egyesült Arab } \\
\text { Emírségek }\end{array}$ & 149. & 130. & 21. \\
\hline Irak & 13. & 1. & 162. \\
\hline Irán & 52. & 39. & 146. \\
\hline Izrael & 67. & 40. & 35. \\
\hline Jemen & 1. & 8. & 177. \\
\hline Jordánia & 69. & 64. & 60. \\
\hline Katar & 141. & 133. & 30. \\
\hline Kuvait & 130. & 75. & 85. \\
\hline Libanon & 44. & 43. & 137. \\
\hline Omán & 133. & 138. & 56. \\
\hline Szaúd-Arábia & 93. & 30. & 51. \\
\hline Szíria & 4. & 4. & 178. \\
\hline
\end{tabular}

4. sz. táblázat. A közel-keleti országok globális rangsorban elfoglalt helyük a Törékeny Állam Index jelentése ${ }^{18}$, a Globális Terrorizmus Index ${ }^{19}$, valamint a Korrupcióészlelési Index alapján.

Nem meglepő módon azon országok hordozzák a legtöbb kockázatot, amelyek belső fegyveres konfliktusokkal küzdenek - Jemen, Szíria, Irak ${ }^{20}$, Líbia - és a legjobban teljesítő országokat tulajdonképpen az Öböl Menti Együttmúködési Tanács tömöríti - Bahrein, Egyesült Arab Emírségek, Katar, Kuvait, Szaúd-Arábia, Omán. A továbbiakban röviden

17 Az országok 1-180 helyezés szerint vannak beosztva, ahol az 1. helyezés a korrupciótól leginkább mentes ország. Forrás: CORRUPTION PERCEPTION INDEX, 2019.

${ }^{18}$ Forrás: https:// fragilestatesindex.org/country-data/

${ }^{19}$ Forrás: GLOBAL TerRORISM INDEX 2019, 2019.

${ }^{20}$ Bár Irakban jelenleg nem zajlik polgárháború, az Iszlám Állam kalifátusának felszámolása óta az ország nem képes konszolidálni a belpolitikai és társadalmi folyamatokat. A 2003ban kezdődő iraki háború óta az ország válságok sorozatával küzdött, amelyek nem tették lehetővé az ország fejlődő pályára állítását - helyzetét tovább nehezíti a szomszédos Szíriában zajló polgárháború, valamint a szintén szomszédos Irán diplomáciai-gazdasági elszigetelése is. 
ismertetem azokat a régióban tapasztalható általános jelenségeket, amelyek a pénzmosás és terrorizmusfinanszírozás elleni küzdelmet nehezítik.

Feloldhatatlan ellentétek a régióban. A helyi társadalmakat és az országokat megannyi politikai, kulturális, vallási, származási, stb. törésvonal tagolja. Ezen törésvonalakat számos állam alatti és állami szereplő is igyekszik kiaknázni lehetőségeik szerint a saját hatalmi helyzetük javítása érdekében. Az Egyesült Államok Szíriát (1979. óta) és Iránt (1984. óta) több évtizede terrorizmust támogató országként tart nyilván ${ }^{21}$, ugyanakkor köztudott tény, hogy az észak-afrikai és közel-keleti országok jelentős része összefüggésbe hozható militáns / terrorista szervezetekkel és átláthatatlan pénzügyi csatornákkal ${ }^{22}$. Ezen szervezetek támogatásai nem ritkán azt a célt szolgálják, hogy egy adott országot destabilizáljanak, ezáltal csökkenjen a hatalmi befolyása a régióban ${ }^{23}$. Elegendő, ha a polgárháborúval sújtott országokra gondolunk, közülük is kiemelkedik Szíria, ahol megannyi ország igyekszik azokat a feleket nyíltan támogatni, amelyekkel valamilyen okból kifolyólag azonosulni tudnak.

Hatalmas bevételek fölött diszponáló országok. A régió több országát a Kőolaj-exportáló Országok Szervezete (angol elnevezés: Organization of the Petroleum Exporting Countires, a továbbiakban röviditve: OPEC) tömöríti, köztük Szaúd-Arábiát, Iránt, Irakot, Kuvaitot, az Egyesült Arab Emírségeket, Líbiát és Algériát ${ }^{24}$. Ezen felül még Omán, Egyiptom, Szíria, Jemen és Bahrein birtokol értékelhető mennyiségű kőolajat a régióban. ${ }^{25}$ Több országra - az Öböl Menti Együttműködési Tanács tagállamai - pozitív hatást gyakorolt a kőolaj, abból erős gazdaságú jóléti államokat tudtak felépíteni, és kialakult egy olyan vagyonos réteg, amely tetszése szerint tud támogatni neki szimpatikus szereplőket / kezdeményezéseket a régióban. A teljesség igénye nélkül, például 2015-ben az Iszlám Állam bevételeinek 5\%-a szaúdi donoroktól származott ${ }^{26}$, Kuvait a Szíriában múködő terrorszervezetek adománygyúitő központjának minősítették 2017-ben ${ }^{27}$, míg Irán 2019-ben 30 millió dollárra emelte a

\footnotetext{
21 STATE SPONSORS OF TERRORISM

${ }^{22}$ Forrás: https://www.govinfo.gov/content/pkg/CHRG-109shrg30837/html/CHRG109shrg $30837 . \mathrm{htm}$

${ }^{23}$ Uo.

${ }^{24}$ Forrás: https://www.opec.org/opec web/en/data graphs/330.htm

25 AOUN, 2013. 134.o.

${ }^{26}$ Is SAUDI ARABIA TO BLAME FOR ISLAMIC STATE? 2015.

27 AOAV, 2017.
} 
palesztin Hamász részére nyújtott pénzügyi támogatást információkért cserébe. $^{28}$

Állami müködés átláthatóságának nehézségei. A nyugati típusú demokratikus államokban általános elvárás az átláthatóság, azaz az állami működés ellenőrizhetősége. Ez a követelmény a fejlődő országok többségében - így az észak-afrikai és közel-keleti országok esetében is korlátozottan érvényesül. Az átláthatóság legfőbb akadályának ismertetéséhez N. Rózsa Erzsébet „reális tér” - „virtuális tér” elméletét veszem alapul. $^{29} \mathrm{Az}$ elmélet szerint a reális térben a politikai-hatalmi működést leginkább az egyszemélyi vezetők döntéseivel lehet megismerni, és az így fennálló partimoniális berendezkedés tulajdonképpen uralkodóalattvaló viszonyt eredményez. Ezzel szemben a virtuális tér a „modern nemzetállamok demokratikus berendezkedéseire emlékeztető struktúrát” takarja, amely kapcsán sokszor torz formában jelentkeznek olyan követelmények, amelyek a nyugati típusú fejlett országokban organikus úton alakultak ki. ${ }^{30}$ Mivel az állam látszólagos és tényleges múködése kettéválik, így sokkal nehezebben megismerhető, ellenőrizhető.

Állami ellenőrzés korlátai. A központi kormányzat több országban nem képes arra, hogy az ország teljes területe felett ellenőrzést gyakoroljon - ez kiváltképpen igaz a polgárháborúval sújtott országokra. A központi kormányzat kapacitáshiánya kedvez az alulról érkező illegális szerveződéseknek - bűnbandák, milíciák, terrorszervezetek -, az országon belül és az országhatárokon átívelő tranzakciók (elsősorban készpénzszállítmányok) láthatatlanságának, stb. Az észak-afrikai és közel-keleti országok földrajzi sajátosságai okán a határvédelem és ellenőrzés is sok esetben nehéz feladat, ami segíti a külföldi harcosok átvonulását és az illegálisan generált bevételek mozgatását.

\section{AZ ÉSZAK-AFRIKAI ORSZÁGOK KOCKÁZATAI AZ FATF JELENTÉSEI TÜKRÉBEN}

A továbbiakban az FATF által publikált jelentések alapján bemutatom az észak-afrikai és közel-keleti országok pénzmosás és terroriz-

\footnotetext{
28 BACHNER - STAFF, 2019.

${ }^{29}$ N. RÓZSA, 2011. 16-17.o.

${ }^{30} \mathrm{Uo}$.
} 
A pénzmosás és terrorizmusfinanszírozás elleni küzdelem az észak-afrikai és közel-keleti régióban

musfinanszírozás ellen irányuló lépéseit, amely alapján a kétoldalú kapcsolatokat is lehetséges elemezni.

Algéria. Jogszabályi szinten a terrorizmus és terrorizmusfinanszírozás, valamint 2004-ben a pénzmosás elleni küzdelem 1995-ben jelent meg. ${ }^{31}$ A szabályozási környezet ugyanakkor számos hiányosságot tartalmazott, hiányoztak a terrorszervezetek és terrorizmussal összefüggésben hozható személyek vagyonbefagyasztására vonatkozó speciális rendelkezések, hiányosak voltak a banki ügyintézéssel kapcsolatos eljárások (például ügyfél azonosítása), de banki ügyfelek kockázatelemzése sem történt meg hosszú ideig. ${ }^{32}$ Jóllehet Algéria pénzügyi tevékenységének volumene okán nem számít kiemelkedő szereplőnek az észak-afrikai régióban, gazdasági bűncselekmények megannyi fajtája jelent rendszerszintû kockázatot - úgy mint korrupció, csempészés, hamisítás, tiltott kereskedelem, drogkereskedelem, stb. A gazdasági bűncselekmények közül több szorosan köthetô terrorista szervezetek múködéséhez, sôt mi több, a helyi bűnszervezetek és terrorista szervezetek között világos kapcsolatok rajzolhatók fel. Algériában 2009. december 6-17. között tartottak helyszíni ellenőrzést pénzmosás és terrorizmusfinanszírozás vonatkozásában, amely során a felszínre jöttek a rendszerszintű kockázatok, valamint a szabályozási környezet megannyi hiányossága. A vizsgálat hatására megszületett országjelentés nyomán Algéria azon országok csoportjába került, amelyeknél súlyos, stratégiai hiányosságokat állapítottak meg a szabályozási környezet vonatkozásában (2011-ben Algériával együtt összesen 26 ilyen országot azonosított az FATF). ${ }^{33}$ Algéria esetében egészen 2016-ig várni kellett arra, hogy ezeket a hiányosságokat az FATF számára korrigálja, és a 2011-ben megfogalmazott akcióterv célkitűzéseit teljesítse. ${ }^{34}$

Egyiptom. 2008. október 12. és 26. közötti helyszíni ellenőrzés nyomán született a 2009-es országjelentés. ${ }^{35}$ A jelentés megállapította, hogy amíg 2002-ben még nyoma sem volt a pénzmosást és terrorizmusfinanszírozást visszaszorító szabályoknak, addig 2008-ra már komplex intézkedések jelentek meg - igaz, foghíjasan, többek között a szervezetbűnözés bizonyos formáit és emberkereskedelmet nem

\footnotetext{
31 Mutual Evaluation Report, 2010. 4.o.

32 Uo. 4-7.o.

33 IMPROVING GLOBAL AML/CFT COMPLIANCE: ON-GOING PROCESS, 2011.

34 Improving GLOBAL AML/CFT COMPLIANCE: ON-GOING PROCESS, 2016.

35 Mutual Evaluation Report, 2009. 9.o.
} 
kriminalizálták, és a terrorszervezetek / terroristák pénzügyi ellehetetlenítése is hiányos volt. A hiányosságokat leszámítva viszont a pénzügyi és nem pénzügyi intézmények szabályozása meglehetősen kiterjedt volt. Algériával, Marokkóval és Tunéziával ellentétben Egyiptom nem került fel a súlyos hiányosságokkal rendelkező országok listájára, az országjelentést mindössze nyomonkövetési eljárás követte (angol elnevezés: regular follow-up process). A 2014-as jelentés elismeri, hogy Egyiptom jelentős lépéseket tett az FATF ajánlásai teljesítésére, ami konklúzióként megállapította, hogy az országo nyomon követését akár meg is lehetne szűntetni. ${ }^{36}$

Líbia. Az észak-afrikai régió legtöbb kockázatát hordozó országa. 2011-ben Moammer Kadhafi bukása magával rántotta az országot, és az azóta eltelt években Líbia több részre szakadva létezik. A nemzetközileg elismert központi kormányzatnak nincs ereje ahhoz, hogy a vele szembenálló hatalmi centrumokat letörje, így korlátozott a cselekvési eszköztára bárminemű szabályozás kikényszerítése tekintetében. Líbiában a terrorizmus, tömeges migráció, fegyver-, drog és emberkereskedelem soha nem látott kockázatot jelent, amely folyamatokat az egymással szembenálló felek, milíciák és törzsek nem képesek visszafogni / sok esetben kiveszik a részüket a folyamatokból.

Marokkó. A terrorizmusfinanszírozás kriminalizálása 2003-ban történt meg, míg a pénzmosással kapcsolatos törvény megalkotására egészen 2007-ig várni kellett. ${ }^{37}$ Marokkóban 2007. január 29. és február 9. között tartottak helyszíni ellenőrzést, tehát a pénzmosással kapcsolatos törvény bevezetésének évében. A vizsgálatból született országjelentés ennek megfelelően megemlíti, hogy mind a jogszabályi környezet, mind az arra épülő intézményrendszer kialakítása gyerekcipőben járt. ${ }^{38}$ De nem volt ez másképpen a terrorizmusfinanszírozással kapcsolatos kérdésekben sem, hiába volt akkor már több évben hatályban rá külön jogszabály meglehetősen hézagos volt a szabályozás. 2012 júniusában Marokkóra még mindig igaz volt, hogy súlyos hiányosságokkal bírt a pénzmosás és terrorizmusfinanszírozás szabályozása tekintetében - bár az FATF álláspontja szerint a politikai vezetés részéről megvolt a kellő elhatározás az ajánlások átültetésére. ${ }^{39}$ 2013-ra sikerült olyan szabályozási környezetet

\footnotetext{
${ }^{36}$ Mutual Evaluation RePORT - 5TH Follow-Up RePORT FOR EGYPT, 2014. 5.o.

${ }^{37}$ Mutual Evaluation Report of the Kingdom of Morocco, 2007. 6.o.

${ }^{38}$ Uo. 6.o.

39 Improving Global AML/CFT COMPLIANCE: ON-GOING PROCESs, 2012.
} 
kialakítani, amely illeszkedett az FATF ajánlásaihoz, és kikerült a nyomonkövetési eljárás alól.

Tunézia. A pénzmosás és drogkereskedelem kriminalizálása már 1992-ben megtörtént, ugyanakkor egészen 2003-ig nem alkalmazták a gyakorlatban..$^{40}$ 2003-ben a nemzetközi stadardokhoz illeszkedő jogszabályt alkottak a pénzmosás és terrorizmusfinanszírozás visszaszorítására, amely nagy mozgásteret adott vagyonbefagyasztásokhoz, lefoglalásokhoz és elkobzásokhoz. A 2000-es években Algériához és Marokkóhoz képest Tunézia jóval előrébb járt a szabályozási környezet és jogalkalmazás tekintetében, az FATF nem is állapított meg stratégiai szintü hiányosságokat. Ezzel ellentétben a 2015. február 16-256. között helyszíni ellenőrzés nyomán megszületett országjelentés már teljesen más képet festett az országról. Ben Ali elnök hatalomból való távozása után megkezdődött az állami intézményrendszer átalakulása, és a belpolitikai szereplők figyelmét az elnöki és képviselői választások kötötték le. Ugyanakkor lassan megkezdődött a pénzmosással és terrorizmusinanszírozással kapcsolatos mechanizmusok újraéledése, ami az ancient regime tagjait sem hagyta érintetlenül (korrupció kapcsán: 2011-ben 42, 2012-ben 99, 2013-ban 159 és 2014-ben 266 ügyet regisztráltak, de ugyanúgy meredeken emelkedtem a csempészéssel és drogkereskedelemmel összefüggő ügyek száma is). ${ }^{41}$ Ugyanakkor a kedvező tendencia nem párosult a szabályozási környezet fejlesztésével, és az átalakuló intézményrendszer következtében foghíjassá váltak az addig meghozott intézkedések. Továbbá több terrorista szervezet is aktivizálódott (például Iszlám Állam), így a szabályozási környezet fejlesztése nagyon is fontos kérdéssé vált. Így az FATF további lépések megtételére sürgette Tunéziát, egyidejűleg 2018-2019. között felkerült a súlyos hiányosságokkal küzdő országok listájára. ${ }^{42}$ A listáról csak 2019 októberében került le, miután az FATF ajánlásaihoz igazodva sikerült a szabályozási környezetet átalakítani.

\footnotetext{
40 Mutual Evaluation Report of the Republic of Tunisia, 2007. 8.o.

${ }^{41}$ Mutual Evaluation RePORT - Tunisia, 2016. 47.o.

42 Improving Global AML/CFT COMPLIANCE: ON-GOING PROCESS, 2019.
} 


\section{A KÖZEL-KELETI ORSZÁGOK KOCKÁZATAI AZ FATF JELENTÉSEI TÜKRÉBEN}

Bahrein. Az ország pénzmosás és terrorizmusfinanszírozás elleni küzdelem mellett való elköteleződését jelzi, hogy a MENAFATF titkársága 2004-ben itt került felállitásra. ${ }^{43}$ Mindezek ellenére az FATF szakértôi szerint Bahrein csak korlátozottan érti meg a pénzmosással és terrorizmusfinanszírozással összefüggő kockázatokat, jóllehet egy stabil és jól működő rezsimet sikerült kialakítani az évek során - 2012. és 2017. között 43 nyomozást folytattak le pénzmosás vonatkozásában. Bahrein esetében azért van szükség az FATF ajánlásainak maradéktalan átültetésére, mivel a közel-keleti régió pénzügyi és kereskedelmi központja, 2016-ban a GDP $16,5 \%$-át tette ki a pénzügyi szektor. ${ }^{44}$ Míg pénzmosás tekintetében Bahrein viszonylag jól szerepel, terrorizmusfinanszírozás kapcsán komoly kockázatok állnak fent, például készpénz kijuttatása az országból vagy civil szervezetek segítségével. ${ }^{45}$

Egyesült Arab Emírségek. A nemzetközi rangsorok alapján a közelkeleti régió egyik legstabilabb országa. 2003. óta fokozatosan kerülnek beépítésre az FATF ajánlásai a szabályozási környezetbe, a pénzmosás 2002ben, a terrorizmusfinanszírozás pedig 2004-ben került kriminalizálásra. ${ }^{46} \mathrm{~A}$ 2007. február 28. és március 15. közötti helyszíni szemlét követően az állam normál nyomonkövetési eljárás alá került, hogy pótolja az FATF ajánlásainak teljeskörű átültetését. Bár az Egyesült Arab Emírségekben a pénzmosás és terrorista aktivitás kockázatai alacsonyak, a terrorizmusfinanszírozás kapcsán annál gyakrabban kerül előtérbe - akárcsak a többi, olajban gazdag ország. Az Egyesült Arab Emírségek egy listán szerepel Szaúd-Arábiával, Katarral és Kuvaittal, amely országokból nagy mennyiségú pénz áramlik terrorista szervezetekhez akár a közel-keleti régióban, akár Afganisztánba és Pakisztánba. ${ }^{47}$ 2020-ban ráadásul újabb kételyek fogalmazódtak meg a pénzmosás elleni intézményrendszer hatékonyságával is kapcsolatosan, így elképzelhető, hogy szorosabb megfigyelés alá fog kerülni a közeljövőben. ${ }^{48}$

\footnotetext{
43 Bahrain to Host New Anit-Money Laundering Regional Body, 2004.

${ }^{44}$ Mutual Evaluation Report - Bahrain, 2018. 4.o.

45 Uo. 4.o.

46 Mutual Evaluation Report - United Arab Emirates, 2008. 9.o.

47 WIKILEAKS CABLES PORTRAY SAUDI ARABIA AS A CASH MACHINE FOR TERRORIST, 2010. 48 UAE AT RISK OF LANDING ON WATCHLIST OVER MONEY LAUNDERING, 2020.
} 
Irak. Az ország 2003. óta meglehetôsen nehéz helyzetben van, köszönhetően az iraki háborúnak, a 2011-es Arab tavasz eseményeinek, az Iszlám Állam kalifátusépítési kísérletének, valamint az azóta tartó politikaigazdasági válságnak. Irak politikai berendezkedése nagymértékben átalakult a Szaddám Husszein rezsim bukása után, és 2004-ben született meg az első jogszabály, amely a pénzmosás ellen lép fel. ${ }^{49}$ A több mint 15 évnyi, folyamatos válsághelyzettel terhelt időszak természetesen nem kedvezett egy jól működő pénzmosás és terrorizmusfinanszírozás elleni rezsim kiépítésére, egyfelől hiányzik hozzá a megfelelő szabályozási környezet, másfelől az állam hatékony fellépése. Ahogy a 4. sz. táblázatból is kitünik, Irakban súlyos problémát jelent a korrupció és a terrorizmus, és számos állam alatti szereplő a saját ízlése szerint alakítja ki a szabályokat. 2013. és 2018. között szerepelt azon országok listáján, amelyek súlyos kockázatokat hordoznak, ugyanakkor érdemes azt is figyelembe venni, hogy a listáról való lekerüléssel párhuzamosan Irakban továbbra is súlyos problémát jelent a pénzmosás és terrorizmusfinanszírozás - és vele együtt a terrorizmus is.

Irán. Észak-Korea mellett Irán a másik olyan ország, amely hosszú idő óta az úgynevezett feketelistán szerepel, amely kifejezetten olyan államokat tartalmaz, amelyek nem hajlandóak együttmúködni / látszólagos együttmúködést színelnek az FATF-el. Irán - Észak-Koreához hasonlóan elutasítja a fennálló globális rendet, és ezáltal a nemzetközi színtér perifériájára szorultak. Az Irán - Egyesült Államok közötti konfliktus 2015ben, az iráni atomalkuval enyhülni látszott, ugyanakkor miután 2018-ban Donald Trump amerikai elnök kiléptette az Egyesült Államokat, újult erôvel folytatódott a két ország közötti konfliktus. Az Egyesült Államok 2019-ben már odáig elment, hogy Irán hivatalos fegyveres testületét, a Forradalmi Gárdát is terrorista szervezetnek nyilvánítsa. ${ }^{50} \mathrm{~A}$ jelenlegi helyzetben, amikor Iránt terrorizmust támogató országként tartják számon, és számos törékeny államban van jelen - Szíria, Jemen, Irak, Palesztin Hatóság - nem értékelhető az FATF standardjai szerint a pénzmosás és terrorizmusfinanszírozás elleni küzdelme.

Izrael. Egyedülálló helyzetben van a közel-keleti régióban, ugyanis nem a MENAFATF, hanem a Európa Tanács Pénzmosás és Terrorizmusfinanszírozás Elleni Szakértői Bizottság (a továbbiakban rövidítve: MONEYVAL) tagja, amely európai és kaukázusi országokat,

\footnotetext{
${ }^{49}$ Mutual Evaluation RePORT - IraQ, 2012. 2.o.

${ }^{50}$ REVOLUTIONARY GUARD CORPS: IRAN HITS BACK AT US TERRORIST CLAIM, 2019.
} 
illetve Oroszországot tömöríti. Alapvető biztonsági érdeke, hogy a pénzmosással és terrorizmusfinanszírozással kapcsolatos kockázatokat a minimálisra szorítsa le - lásd arab-izraeli háborúk és a Palesztin Hatóság ezáltal csökkentse az ellene irányuló gazdasági és katonai támadások esélyeit. A régióban a legnagyobb számban indított pénzmosás elleni nyomozásokat, 2014. és 2017. között összesen 415. esetben. ${ }^{51}$ A terrorizmus elleni küzdelemben Izraelnek nem ritkán katonai eszközökkel is helyt kell állnia, ami túlnyomó részt a Palesztin Hatóság és a libanoni Hezbollah, valamint a Szíria területén állomásozó, iráni támogatást élvező milíciák részéről jelentkezik. Nem véletlen, hogy az első, pénzmosás visszaszorítására vonatkozó jogszabály már 2000-ben megszületett. ${ }^{52}$

Jemen. 2003-ben hirdették ki azt a törvényt, amely a pénzmosás visszaszoritása érdekében viszonylag széleskörű szabályozást tartalmazott (bár közel sem felelt meg teljesen az FATF módszertanának). Az FATF szakértők 2007. július - augusztus között tartottak helyszíni szemlét, ekkor még egészen új volt az országos szisztéma. ${ }^{53}$ Másfelől viszont a terrorizmusfinanszírozással, és terrorista szervezetek / terroristák jogszabályi eszközökkel történő ellehetetlenítése nem jelent meg, ami súlyos hiányosságot jelentett. Bár az országjelentés után a központi kormányzat kidolgozott egy akciótervet a hiányosságok kiküszöbölésére, annak megvalósítására már nem volt lehetôségük. 2011-ben az Arab tavasz Jement is elérte, és addig fennálló politikai viszonyok azonnal felborultak. 2012-ben felkerült az FATF azon országok listájára, amelyek súlyos hiányosságokat mutatnak pénzmosás és terrorizmusfinanszírozás tekintetében, és mind a mai napig állandó szereplője. ${ }^{54}$ 2015-ben a belpolitikai feszültségek polgárháborúhoz vezettek, amely több részre szakította az országot. İgy hasonlóan Líbiához és Szíriához, a központi kormányzat nem képes a hatalmát a teljes ország felett gyakorolni, amely következtében bizonyos területek a saját törvényeik szerint múködnek - és ezt természetesen szélsőséges csoportok, militáns szervezetek kihasználják.

Jordánia. A közel-keleti régió egyik legfiatalabb pénzmosás és terrorizmusfinanszírozás elleni szabályozási környezetével rendelkezik, amely 2007-ben lépett hatályba. ${ }^{55}$ Mindez azonban nem volt gátja annak,

\footnotetext{
${ }^{51}$ Mutual Evaluation RePORT - IsRael, 2018. 3.o.

52 Uo. 22.o.

53 Mutual Evaluation RePORT - Yemen, 2008. 6.o.

${ }^{54}$ FATF PUBLIC STATEMENT, 2012.

55 Mutual Evaluation Report - Jordan, 2009. 5.o.
} 
hogy Jordánia az egyik legfejlettebb és legstabilabb gazdasági rendszerét múködtesse, kiváltképpen a bankszektor esetében.$^{56} \mathrm{~A}$ jordániai szabályozási környezet kellőképpen reflektált az FATF ajánlásaira, kevés kivétellel sikeresen átültette azokat a hazai jogszabályi környezetbe. A soron következő helyszíni szemlére mintegy 10 évvel később, 2018. július 8-23. között került sor. A vizsgálat idején a bankszektor a teljes pénzügyi szektor tevékenységének 70\%-át fedte le, amely továbbra is kellőképpen stabilnak bizonyult. ${ }^{57}$ 2017-ben a nemzeti kockázatértékelés keretein belül azonosították a kockázati tényezőket, amelyek közül kiemelkedtek az adóelkerülésből, rablásból, és drogkereskedelemből származó bevételek. A 2007es jogszabályhoz a tíz év alatt további kiegészítéseket tettek, ezáltal a pénzmosás és terrorizmusfinanszírozás elleni jogszabályi környezet még komplexebbé vált. Az FATF szerint ugyanakkor Jordánia mérsékelt módon végezte el a kockázatok azonosítását és a jogszabályok fejlesztését, amelyet a felderített ügyek száma is jól mutat: 2013. és 2017. között mindössze 78 gyanús esetet vizsgáltak ki, amelyből 57 került bíróságok elé. ${ }^{58}$ Továbbá mindenképpen előremutató az, hogy jóllehet a polgárháborús Szíriával és a meglehetősen instabil Irakkal szomszédos, a terrorizmus okozta veszély alacsony.

Katar. A 2010-es országjelentés megemlíti, hogy a pénzmosás egy 2002-es törvénnyel kriminalizálásra került, mindazonáltal maga a tevékenység meglehetősen szúken volt értelmezve. ${ }^{59}$ Hasonlóan jártak el a terrorizmusfinanszírozás 2004-es kriminalizálásával is. A rendszer alacsony hatékonyságát jelzi, hogy 2002. és 2010. között mindössze egetlen alkalommal foglalkoztak bíróság előtt pénzmosás vádjával, ugyanakkor ezt nehéz elképzelni arról az országról, ahol a pénzügyi szektor a legdinamikusabb ütemben bővült a régióban. ${ }^{60}$ Mindezek ellenére Katar a KözelKelet egyik legstabilabb országa, amelyet a terrorizmus is csak kisebb mértékben veszélyeztet. A terrorizmusfinanszírozás kapcsán ugyanez már kevésbé mondható el, az elmúlt években több olyan támadás is érte az országot, miszerint állami szinten támogatják a terrorizmust a régióban többek között Donald Trump amerikai elnök részéről 2017-ben. ${ }^{61}$ A vádak

\footnotetext{
56 Uo. 5.0

57 The Hasemite Kingdome of Jordan Mutual Evaluation Report, 2019. 5.o.

${ }^{58}$ Uo. 8.

${ }^{59}$ Mutual Evaluation RePORT - QATAR, 2010. 9.o.

${ }^{60}$ Uo. 18.o.

61 Trump SCOLDS QATAR AS TILLERSON SEEKS TO EASE CRISIS, 2017.
} 
kézzelfogható formát is öltöttek Katarral szemben, 2017-ben többek között Szaúd-Arábia, az Egyesült Arab Emírség, Bahrein, Egyiptom, Jordánia, a nemzetközileg elismert líbiai és jemeni kormány is csatlakozott a blokádhoz, amely visszavágta Katar mozgási lehetőségeit.

Kuvait. 2002-ben született meg a pénzmosás elleni jogszabály, ami nem irányult egyben a terrorizmusfinanszírozás felszámolására. ${ }^{62}$ Helyszíni szemlére 2010. október 17. és november 1. között került sor, amely során a kuvaiti pénzmosás és terrorizmusfinanszírozás elleni szabályozási környezet kapcsán számos súlyos megállapítást tettek az FATF szakértői. Bár az országjelentés kitér arra, hogy Kuvaitban a pénzmosás és terrorizmusfinanszírozás nem jelent túlzott kockázatot, a szabályozási környezet hiányosságai okán mégis sérülékeny ország 2012. és 2015. között felkerült azon országok listájára, amelyek súlyos hiányosságokkal küzdenek. ${ }^{63} 2012$ ben fogadtak el akciótervet az akkor felmerülő kockázatok kiküszöbölésére, és három évbe tellett, ameddig a szabályozási környezetet az FATF ajánlásaihoz tudták igazítani. A pénzmosás ugyanakkor továbbra is potenciális kockázat maradt, 2015-ben a bankszektor 188 milliárd USD felett diszponált, és elsősorban az Irakból érkező, valamint oda irányuló tranzakciók hordoznak kockázatokat.

Libanon. Egy meglehetôsen különleges politikai-társadalmi berendezkedésű országról van szó, amely területén egészen 2005-ig szíriai csapatok állomásoztak. 2011-ben aztán a szíriai polgárháború gyủrűzött be Libanonba, és jelenleg 1,5 millió szíriai menekült tartózkodik az országban. Állam az államban működik a hírhedt Hezbollah nevű szervezet, amelyet több ország is terrorista szervezetként bélyegez meg, amely együttmúködik a szíriai központi kormányzattal és Iránnal. Libanon a szomszédos polgárháború jelentette nehézségek, valamint a menekültáradat okán súlyos társadalmi-gazdasági válságba került, amely 2020-ban oda vezetett, hogy államcsőd közeli helyzetbe került. ${ }^{64}$ A Libanonról készült országjelentés a két fordulópont dátum között, 2009-ben jelent meg, amely nyomán normál nyomonkövetési eljárás alá került az ország. Bár Libanon az elmúlt években együttmúködött az FATF szakértőivel, és 2017-ben javaslat született arra vonatkozóan, hogy kikerüljön a nyomonkövetési eljárás alól ${ }^{65}$, nem lehet

\footnotetext{
62 Mutual Evaluation - State of Kuwait, 2011.

63 Improving GLOBAL AML/CFT COMPLIANCE: ON-GOING PROCESS, 2015.

${ }^{64}$ CORNISH, 2020.

65 Mutual Evaluation Report - 9TH FOLlow-Up REPORT FOR THE LEBANESE REPUBLIC, 2017.
} 
eltekinteni attól, hogy komoly kockázatokkal bír akár a szomszédos Szíria, akár a területén múködő terrorista / militáns szervezetek kapcsán.

Omán. Az első pénzmosással kapcsolatos jogszabályt 2002-ben fogadták el, amelyet 2010-ben egy komplexebb, pénzmosással és terrorizmusfinanszírozással is foglalkozó váltott fel. ${ }^{66}$ A jogszabályban rejlő lehetőségeket azonban a bűnüldöző szervek és a bíróságok nem aknázták ki kellőképpen, 2003. és 2011. között pénzmosásért mindössze néhány ember, míg terrorizmusfinanszírozás kapcsán senkit sem ítéltek el. ${ }^{67}$ Bár a nemzetközi rangsorokból az látszik, hogy Omán a közel-keleti régió egyik legkevésbé kockázatos állam a téma szempontjából, mégis a polgárháborús Jemen mellett fekszik, valamint csak az Ománi-öböl választja el a feketelistán lévő Irántól, ami megnöveli az ország sérülékenységét. Mindezek ellenére az Ománban elkövetett bűncselekmények száma régiós szinten alacsony.

Szaúd-Arábia. A 2001. szeptember 11-i terrortámadásokért közvetlenül 19 ember volt felelős, közülük 15 szaúdi állampolgár volt. ${ }^{68} \mathrm{Ez}$ volt az a merényletsorozat, ami a világ figyelmét ráirányította a terrorizmusfinanszírozás fontosságára, és nem utolsó sorban a nemzetközi közösség azonnal a közel-keleti régió egyik legerôsebb államára kezdett fókuszálni. Szaúd-Arábia nem sokkal a merényletsorozat után, 2003-ban vezetett be pénzmosás és terrorizmusfinanszírozás visszaszorítására irányuló jogszabályokat és intézkedéseket, ugyanakkor pénzmosással kapcsolatos esetek már a hatályba lépés előtt is bíróság elé kerültek. ${ }^{69}$ Az országban 2009. március 1-11. között került sor helyszíni szemlére, amelyet egy újabb követett 2017. november 8. és 23. között. A helyszíni szemlékre, valamint az erős lábakon álló jogszabályi környezetre azért van szükség, mivel SzaúdArábia három törékeny ország övezi - Szíria, Irak, Jemen - így erőteljesen kitett határon átívelő illegális tevékenységeknek. A legnagyobb kockázati tényezôk között a drogkereskedelem, korrupció, termékek hamisítása és csempészés szerepel, továbbá az adóelkerülés, emberkereskedelem, stb. is meghatározó. ${ }^{70}$ A Nemzetközi Valutaalap becslése szerint a GDP 2-5\%-a esik a pénzmosás áldozatául, továbbá a terrorizmusfinanszírozás is kiemelt jelentôségû. Szintén becslés, de 2000. és 2018. között mintegy 3.000 külföldi

\footnotetext{
${ }^{66}$ Mutual Evaluation Report of the Sultane of OMAn, 2011. 8.o.

${ }^{67}$ Uo. 9.o.

68 US TO REVEAL SAUDI OFFICIAL ALLEGEDLY TIED TO 9/11 ATTACKERS, 2019.

${ }^{69}$ Mutual Evaluation Report - Kingdom of SAudi Arabia, 2010. 6.o.

${ }^{70}$ Mutual Evaluation Report - Kingdom of Saudi Arabia, 2018. 1.o.
} 
harcos érkezett az országba, akik akár belföldön, akár a szomszédos államokba utazva súlyos kockázatot jelentenek. ${ }^{71}$ Az illegális tevékenységek volumene dollár milliárdokban mérhető, amely pénz viszont nem marad meg az ország határain belül - a szaúdi hatóságok 70-80\% közé teszik az illegális tevékenységekből származó bevételek kiáramlását. ${ }^{72}$ Mindezen kockázatok mellett Szaúd-Arábia elkötelezett a pénzmosás és terrorizmusfinanszírozás visszaszorításában, hiszen a közel-keleti régió legfejlettebb és a nemzetközi piacokra leginkább beágyazott ország számára létfontosságú minden olyan kockázat visszaszorítása, amely a nemzetközi piacokon rontja az esélyeit. A témára fókuszálva stratégiát dolgoztak ki, illetve 2017-ben akciótervet fogadtak el a kockázatok csökkentése érdekében.

Szíria. Dacára annak, hogy Szíria több szempontból is tranzitország (például drogcsempészés tekintetében), csak viszonylag későn, 2003-ban és 2005-ben született nemzetközi standardokhoz igazodó pénzmosás és terrorizmusfinanszírozás ellenes jogszabályi környezet. ${ }^{73}$ A 2006-os helyszíni ellenőrzés során tapasztaltak arra juttatták az FATF szakértőit, hogy Szíriában a megannyi kedvezőtlen feltétel ellenére alacsony a pénzmosás kockázata, mivel a pénzügyi szektor viszonylag kevés szereplővel működött (például 6 állami és 7 magánbank) és nem volt kiterjedtnek mondható. A 2000-2010. közötti időszakban a központi kormányzat nyitott a nemzetközi piacokra, több intézkedéssel is igyekezett új befektetőket megszólítani, amely folyamatot a 2011-ben kirobbanó tüntetések, majd polgárháború félbetört. A polgárháború során Szíria több részre szakadt, amely helyzetet 2014-ben az Iszlám Állam kalifátusának kikiáltása is tovább fokozott. A központi kormányzat értelemszerűen elvesztette azon képességét, hogy ellenőrizze az ország teljes területét, így különböző milíciák, terrorcsoportok és bűnszervezeteket szabadon végezhették / végezhetik illegális tevékenységeiket. Ennek következtében Szíria már 2011-ben felkerült azon országok közé ${ }^{74}$, amelyek súlyos rendszerszintű kockázatokat hordoznak magukban, és amely listán napjainkig állandó tag. ${ }^{75}$ A helyzet érdekessége, hogy bár a központi kormányzat részéről megvolt a politikai szándék az FATF ajánlásainak megtartására, arra a polgárháború miatt nem volt lehetősége érdemben reagálni. Az FATF szakértői az első adandó alkalommal

\footnotetext{
${ }^{71}$ Uo. 2.o.

72 Uo. 3.

73 Mutual Evaluation Report of the Syrian Arab Republic, 2006. 6.o.

${ }^{74}$ FATF PUBLIC STATEMENT, 2011.

75 Improving GLOBAL AML/CFT COMPLIANCE: ON-GOING PROCESS, 2019.
} 
szeretnének helyszíni szemlét tartani Szíriában, amelynek időpontja kétséges, a polgárháború kimenetelétől függ. ${ }^{76}$

\section{KONKLÚZIÓ}

A tanulmányban az FATF dokumentumaira támaszkodva az északafrikai és közel-keleti régió általános és országspecifikus kockázatait mutattam be a pénzmosás és terrorizmusfinanszírozás visszaszorítását célzó szabályozási környezet fóbb vonalaival egyetemben. Mint az látható, az országok között markáns különbség mutatkozik akár a szabályozási környezet fejlettsége, akár az ajánlások átültetésének lehetősége, valamint a tényleges politika elköteleződés tekintetében. A vizsgált régió legkevésbé kompromisszumképes országa egyértelműen Irán, amely ország évtizedek óta éles szembenállást tanúsít a nyugati országokkal, elsősorban az Egyesült Államokkal szemben. Lehetôségek tekintetében korlátozott a polgárháborúval sújtott országok cselekvési eszköztára, míg a különböző politikai, gazdasági, társadalmi, stb. válságokkal sújtott országok is sokszor nem képesek / hajlandók a szabályozási környezet fejlesztésére.

Mindezekkel összevetve az észak-afrikai és közel-keleti régióban kiemelten fontos szakpolitika a pénzmosás és terrorizmusfinanszírozás elleni küzdelem, nemcsak a régiós biztonsági helyzet javitása tekintetében, hanem az innen tovagyűrűző negatív hatások csillapítása érdekében is - úgy mint terroristák beszivárgása az Európai Unió területére, vagy további afrikai országokban megjelenő terrorista szervezetek (lásd Iszlám Állam). Bár a régió biztonsági kihívásaiból kifolyólag nem látszik a pénzmosás és terrorizmusfinanszírozás elleni küzdelem vége, annyit mégis érdemes megjegyezni, hogy a helyzet konszolidálása csak folyamatos nyomonkövetéssel és újabb ajánlások megfogalmazásával lehetséges.

\section{FELHASZNÁLT IRODALOM}

AOAV( 2017): Key sponsors and donors: Kuwait, AOAV - ACTION on Armed Violence. Elérhető: https://aoav.org.uk/2017/key-sponsorsdonors-kuwait/ (Letöltve: 2020.04.10.)

76 JURISDICTIONS UNDER INCREASED MONITORING, 2020. 
Aoun, Marie-Claire (2013): Oil and Gas Resources of the Middle East and North Africa: A Course or a Blessing? in: Chevalier JM., Geoffron P. (eds) The New Energy Crisis. Palgrave Macmillan, London

Bachner, Michael - Staff, Toi (2019): Iran said increasing Hamas funding to $\$ 30 \mathrm{~m}$ per month, wants intel on Israel, The Times of Israel. Elérhető: https://www.timesofisrael.com/iran-agrees-to-increase-hamas-fundingto-30-million-per-month-report/ (Letöltve: 2020.04.10.)

Bahrain to Host New Anti-Money Laundering Regional Body (2004), Middle East and North Africa Financial Action Task Force. Elérhető: http://www.menafatf.org/information-center/bahrain-host-new-antimoney-laundering-regional-body (Letöltve: 2020.04.10.)

Consolidated Processes and Procedures for Mutual Evaluations and FollowUp (2019), Financial Action Task Force. Elérhető: https://www.fatfgafi.org/publications/mutualevaluations/documents/universalprocedures.html (Letöltve: 2020.04.10.)

Cornish, Chloe (2020): Lebanon set to default for first time as foreign currency reserves dicve, Financial Times. Elérhetô: https://www.ft.com/content/bda10536-6145-11ea-a6cd-df28cc3c6a68 (Letöltve: 2020.04.10.)

Corruption Perception Index (2019), Transparency International. Elérhető: https://www.transparency.org/cpi2019 (Letöltve: 2020.04.10.

FATF Public Statement (2011), Financial Action Task Force. Elérhető: http://www.fatf-gafi.org/countries/st/turkey/documents/fatfpublicstatement-28october2011.html (Letöltve: 2020.04.10.)

FATF Public Statement (2012), Financial Action Task Force. Elérhető: http://www.fatf-gafi.org/countries/st/turkey/documents/fatfpublicstatement-19october2012.html

Global Terrorism Index 2019 (2019), Institute for Economics \& Peace. Elérhető: http://visionofhumanity.org/app/uploads/2019/11/GTI2019web.pdf (Letöltve: 2020.04.10.)

Improving Global AML/CFT Compliance: on-going process (2011), Financial Action Task Force. Elérhető: http://www.fatfgafi.org/countries/a-

c/argentina/documents/improvingglobalamlcftcomplianceongoingprocess-28october2011.html (Letöltve: 2020.04.10.)

Improving Global AML/CFT Compliance: on-going process (2013), Financial Action Task Force. Elérhető: https://www.fatf- 
A pénzmosás és terrorizmusfinanszírozás elleni küzdelem az észak-afrikai és közel-keleti régióban

gafi.org/documents/documents/fatf-compliance-oct-2013.html

(Letöltve: 2020.04.10.)

Improving Global AML/CFT Compliance: on-going process (2015), Financial Action Task Force. Elérhető: http://www.fatfgafi.org/countries/j-m/kuwait/documents/fatf-compliance-february-

2015.html (Letöltve: 2020.04.10.)

Improving Global AML/CFT Compliance: on-going process (2019), Financial Action Task Force. Elérhető: https://www.fatfgafi.org/publications/high-risk-and-other-monitored-

jurisdictions/documents/fatf-compliance-october-2019.html (Letöltve: 2020.04.10.)

Jurisdictions under Increased Monitoring (2020), Financial Action Task Force. Elérhető: $\quad$ http://www.fatf-gafi.org/countries/di/iceland/documents/increased-monitoring-february-2020.html (Letöltve: 2020.04.10.)

Methodology - Standard country or area codes for statistical use (M49), United Nations Statistics Division. Letöltés helye: https://unstats.un.org/unsd/methodology/m49/(Letöltve: 2020.04.10.) Mutual Evaluation Report - 9th Follow-Up Report for the Lebanese Republic (2017), Middle East and North Africa Financial Action Task Force. Elérhető: $\quad$ http://www.menafatf.org/informationcenter/menafatf-publications/ninth-follow-report-lebanese-republic (Letöltve: 2020.04.10.)

Mutual Evaluation - State of Kuwait (2011), Middle East and North Africa Financial Action Task Force. Elérhető: http://www.fatfgafi.org/countries/j-

$\mathrm{m} /$ kuwait/documents/mutualevaluationofthestateofkuwait.html (Letöltve: 2020.04.10.)

Mutual Evaluation Report (2010), Middle East and North Africa Financial Action Task Force. Elérhető: http://www.menafatf.org/informationcenter/menafatf-publications/mutual-evaluation-report-peoplesdemocratic-republic (Letöltve: 2020.04.10).

Mutual Evaluation Report - Bahrain (2018), Middle East and North Africa Financial Action Task Force. Elérhető: http://www.fatfgafi.org/countries/a-c/bahrain/documents/mer-bahrain-2018.html (Letöltve: 2020.04.10.)

Mutual Evaluation Report - Egypt (2009), Middle East and North Africa Financial Action Task Force. Elérhető: 
http://www.menafatf.org/information-center/menafatfpublications/mutual-evaluation-report-arab-republic-egypt (Letöltve: 2020.04.10.)

Mutual Evaluation Report - Iraq (2012), Middle East and North Africa Financial Action Task Force. Elérhetô: http://www.menafatf.org/information-center/menafatfpublications/mutual-evaluation-report-republic-iraq (Letöltve: 2020.04.10.)

Mutual Evaluation Report - Israel (2018), Council of Europe. Elérhető: http://www.fatf-gafi.org/media/fatf/documents/reports/mer4/MERIsrael-2018.pdf (Letöltve: 2020.04.10.)

Mutual Evaluation Report - Jordan (2009), Middle East and North Africa Financial Action Task Force. Elérhető: http://www.menafatf.org/information-center/menafatfpublications/mutual-evaluation-report-hashemite-kingdom-jordan (Letöltve: 2020.04.10.)

Mutual Evaluation Report - Kingdom of Saudi Arabia (2010), Middle East and North Africa Financial Action Task Force. Elérhető: http://www.fatf-gafi.org/countries/s-

t/saudiarabia/documents/mutualevaluationofthekingdomofsaudiarabia.h tml (Letöltve: 2020.04.10.)

Mutual Evaluation Report - Kingdom of Saudi Arabia (2018), Middle East and North Africa Financial Action Task Force. Elérhető: http://www.fatf-gafi.org/countries/s-t/saudiarabia/documents/mersaudi-arabia-2018.html (Letöltve: 2020.04.10.)

Mutual Evaluation Report - Qatar (2010), Middle East and North Africa Financial Action Task Force. Elérhető: http://www.fatfgafi.org/countries/n-r/qatar/documents/mutualevaluationofqatar.html (Letöltve: 2020.04.10.)

Mutual Evaluation Report - Tunisia (2016), Middle East and North Africa Financial Action Task Force. Elérhető: http://www.menafatf.org/information-center/menafatfpublications/mutual-evaluation-report-republic-tunisia-may-2016 (Letöltve: 2020.04.10.)

Mutual Evaluation Report - United Arab Emirates (2008), ), Middle East and North Africa Financial Action Task Force. Elérhető: http://www.menafatf.org/information-center/menafatf- 
A pénzmosás és terrorizmusfinanszírozás elleni küzdelem az észak-afrikai és közel-keleti régióban

publications/mutual-evaluation-report-united-arab-emirates

(Letöltve: 2020.04.10.)

Mutual Evaluation Report - Yemen (2008), Middle East and North Africa Financial Action Task Force. Elérhetô: http://www.menafatf.org/information-center/menafatfpublications/mutual-evaluation-report-republic-yemen (Letöltve: 2020.04.10.)

Mutual Evaluation Report - 5th Follow-Up Report for Egypt (2014), Middle East and North Africa Financial Action Task Force. Elérhető: http://www.menafatf.org/information-center/menafatfpublications/fifth-follow-report-egypt (Letöltve: 2020.04.10.)

Mutual Evaluation Report of the Kingdom of Morocco (2007), Middle East and North Africa Financial Action Task Force. Elérhető: http://www.menafatf.org/information-center/menafatfpublications/mutual-evaluation-report-kingdom-morocco 2020.04.10.)

Mutual Evaluation Report of the Hasemite Kingdom of Jordan (2009), Middle East and North Africa Financial Action Task Force. Elérhető: http://www.menafatf.org/information-center/menafatfpublications/mutual-evaluation-report-hashemite-kingdom-jordan (Letöltve: 2020.04.10.)

Mutual Evaluation Report of the Republic of Tunisia (2007), Middle East and North Africa Financial Action Task Force. Elérhető: http://www.menafatf.org/information-center/menafatfpublications/mutual-evaluation-report-republic-tunisia (Letöltve: 2020.04.10.)

Mutual Evaluation Report of the Sultane of Oman (2011), Finanacial Action Task Force. Elérhető: http://www.fatf-gafi.org/countries/nr/oman/documents/mutualevaluationofthesultanateofoman.html (Letöltve: 2020.04.10.)

Mutual Evaluation Report of the Syrian Arab Republic (2006), Middle East and North Africa Financial Action Task Force. Elérhető: http://www.menafatf.org/information-center/menafatfpublications/mutual-evaluation-report-syria-anti-money-laundering-and (Letöltve: 2020.04.10.)

Is Saudi Arabia to blame for Islamic State? (2015), BBC News. Elérhető: https://www.bbc.com/news/world-middle-east-35101612 (Letöltve: 2020.04.10.) 
N. Rózsa Erzsébet (2011): 9/11 és az arab világ, Nemzet és Biztonság. 1421.o.

Elérhetô:

http://www.nemzetesbiztonsag.hu/cikkek/n rozsa erzsebet-

911 es az arab vilag.pdf (Letöltve: 2020.04.10.)

N. Rózsa Erzsébet (2015): Az arab tavasz - A Közel-Kelet átalakulása, Osiris Kiadó - Külügyi és Külgazdasági Intézet, Budapest

Revolutionary Guard Corps: Iran hits back at US terrorist claim (2019? BBC News. Elérhető: https://www.bbc.com/news/world-us-canada47865522 (Letöltve: 2020.04.10.)

State Sponsors of Terrorism, Bureau of Counterterrorism. Elérhető: https://www.state.gov/state-sponsors-of-terrorism/

The Hasemite Kingdome of Jordan Mutual Evaluation Report (2019), Financial Action Task Force. Elérherő: http://www.fatfgafi.org/publications/mutualevaluations/documents/mer-jordan2020.html (Letöltve: 2020.04.10.)

Tóth Zoltán Balázs (2018): Államépítési törekvések Szíriában II. - Az Iszlám Állam tündöklése és túlékése, Jog-Állam-Politika, 2018/3. szám

Tóth Zoltán Balázs (2019a): A pénzmosás és terrorizmusfinanszírozás elleni küzdelem jelentősége - A nemzetközi és hazai intézmények bemutatása in Baráth Noémi - Mezei József (szerk.): Rendészet-tudományi aktualitások: A rendészettudomány a fiatal kutatók szemével, Doktoranduszok Országos Szövetsége - Rendészettudományi Osztálya, Budapest

Tóth Zoltán Balázs (2019b): A pénzmosás és terrorizmusfinanszírozás visszaszorítását célzó szabályozási környezet vizsgálata az Európai Unió esetében I., Szakmai Szemle, XVII. évfolyam 3. szám. Elérhetô: http://www.knbsz.gov.hu/hu/letoltes/szsz/2019 3 szam.pdf (Letöltve: 2020.04.10.)

Tóth Zoltán Balázs (2019c): A pénzmosás és terrorizmusfinanszírozás visszaszorítását célzó szabályozási környezet vizsgálata az Európai Unió esetében II., Szakmai Szemle, XVII. évfolyam 4. szám. Elérhető: https://www.knbsz.gov.hu/hu/letoltes/szsz/2019 4 szam.pdf

(Letöltve: 2020.04.10.)

Trump scolds Qatar as Tillerson seeks to ease crisis (2017), The Reuters. Elérhető: $\quad$ https://www.reuters.com/article/us-gulf-qatar-sanctionsidUSKBN18Z2ZU (Letöltve: 2020.04.10.)

UAE at risk of landing on watchlist over money laundering (2020), Al Jazeera. Elérhető: https://www.aljazeera.com/ajimpact/uae-risk- 

régióban

landing-watchlist-money-laundering-200430151520708.html (Letöltve: 2020.04.30.)

US to reveal Saudi official allegedly tied to 9/11 attackers (2019), Al Jazeera. Elérhetô: $\quad$ https://www.aljazeera.com/news/2019/09/reveal-saudiofficial-allegedly-tied-911-attackers-190913011926350.html (Letöltve: 2020.04.10.)

Vass György (2017): A terrorizmus finanszírozása elleni küzdelem nemzetközi aspektusai, PhD értekezés. Elérhető: https://nkerepo.uninke.hu/xmlui/bitstream/handle/123456789/12362/vass gyorgy doktor i_ertekezes 2017.pdf?sequence $=1$ (Letöltve: 2020.04 .28 .)

WikiLeaks cables portray Saudi Arabia as a cash machine for terrorist (2010), The Guardian. Elérhető: https://www.theguardian.com/world/2010/dec/05/wikileaks-cablessaudi-terrorist-funding (Letöltve: 2020.04.10.) 